\title{
Viviane Reding on her action in the field of the information society and media (2004-2010) Interview by Elena Danescu
}

\section{Elena Danescu}

To cite this article: Elena Danescu (2020): Viviane Reding on her action in the field of the information society and media (2004-2010) Interview by Elena Danescu, Internet Histories, DOI: $10.1080 / 24701475.2020 .1742533$

To link to this article: https://doi.org/10.1080/24701475.2020.1742533

\section{Published online: 21 Apr 2020.}

Submit your article to this journal $₫$

View related articles $Ґ$

View Crossmark data $\widetilde{ }$ 